\title{
Energy labeling and the economic viability in residences of the project My House My Life
}

\author{
Etiquetagem energética e a viabilidade econômica em residências do \\ programa Minha Casa Minha VIda
}

\author{
Thales Tati Gonçalves Vicente' \\ Elaise Gabriel" \\ Ursula Maira Maciel Rigon"II \\ Marlon Leão'v
}

\begin{abstract}
The significant increase in the electricity consumption over the past decades by the residential sector has stimulated the creation of initiatives which are aiming the energy efficiency (EE). In addition to laws that were enacted in order to increase EE, it was launched in 2012 the Quality Technical Regulation for Energy Efficiency Level of Residential Buildings (RTQ-R), which it sets parameters to be followed in the labeling of an Autonomous Housing Unit (UH). This research had as objective proposes alternatives to increase the energy efficiency level of a residential complex named My House My Life (Minha Casa Minha Vida - MCMV). Moreover, it was calculated the construction costs and evaluated the economic viability of the investment. Thus, it was evaluated the envelope and the water heating system through prescriptive method. The obtained results classified the current housing as D level and showed that a few changes are needed to reach the level $A$. Through thermal energy simulation it was determined by the new classification a reduction of $2 / 3$ in electricity consumption. The increase in the construction costs to achieve the level $A$ is lower than the cost savings over the building's lifetime. Currently, the Selic rate of $14.25 \%$ unfeasible the investment due to the opportunity cost, becoming feasible with the kWh cost higher than $\mathrm{R} \$ 0.97$ or with basic interest rates lower than $9.5 \%$.
\end{abstract}

Keywords: Energy efficiency; Economic viability; Prescriptive method; Thermal energy simulation; RTQ-R

\section{Resumo}

O aumento significativo no consumo de energia elétrica apresentado nas últimas décadas pelo setor residencial, estimulou a criação de iniciativas que visam a eficiência energética (EE). Além de leis que foram

' Engenheiro civil na ICF Construtora Inteligente, Rondonópolis, MT, Brasil - thales.tati@hotmail.com

"Mestranda em Engenharia Civil, Universidade Federal de Santa Maria, RS, Brasil - elaisegabriel@hotmail.com "'Engenheira Civil, Universidade do Estado de Mato Grosso, MT, Brasil - ursula.maciel@yahoo.com.br IVOrientador colaborador do mestrado em Ciências Ambientais, Universidade de Cuiabá, MT, Brasil leao@unemat.br 
sancionadas com a finalidade de aumentar a EE, no ano de 2012 foi lançado o Regulamento Técnico da Qualidade para o Nível de Eficiência Energética de Edificações Residenciais (RTQ-R), que define parâmetros a serem seguidos na etiquetagem de uma Unidade Habitacional Autônoma (UH). Esta pesquisa teve como objetivo propor alternativas para aumentar o nível de eficiência energética de um conjunto residencial do Minha Casa Minha Vida (MCMV), bem como levantar os custos para executá-los e avaliar a viabilidade econômica do investimento. Para tal, foram avaliados a envoltória e o sistema de aquecimento de água através do método prescritivo. Os resultados obtidos classificaram as atuais moradias no nível $D$ e mostraram que poucas alterações são necessárias para atingir o nível A. Através de simulação termo-energética foi determinada com a nova classificação uma redução de $2 / 3$ no consumo de energia elétrica. $O$ aumento nos custos de construção para alcançar o nível A são inferiores à economia proporcionada ao longo do tempo de vida da edificação. Atualmente a taxa Selic de 14,25\% inviabiliza o investimento pelo custo de oportunidade, se tornando viável com o custo do kWh superior a $\mathrm{R} \$ 0,97$ ou com taxa de juros básicos inferiores a 9,5\%.

Palavras-chave: Eficiência energética; Viabilidade econômica; Método prescritivo; Simulação termoenergética; RTQ-R 


\section{Introduction}

With the oil crises in the 70's, there was a concern about the scarcity of this resource. Researches on new energy sources were started in order to reduce the dependence on an increasingly expensive and non-renewable product. However, investing in a new energy source at that time would have higher costs and would require a certain time for implementation, so rational energy use has come to be applied as the most beneficial alternative (PNEF, 2011).

In order to reduce energy consumption, in the 1980s, energy efficiency actions were created with emphasis on the Brazilian Labeling Program (PBE) and the National Program for the Conservation of Electric Energy (PROCEL), both created in order to increase the efficiency of products and inform the consumer which product is most efficient (BRASIL, 2006).

In 2001, after the Brazilian energy crisis, Law 10.295/2001 was promulgated, which it provides for the National Policy on the Conservation and Rational Use of Energy and other measures. This law establishes maximum levels of specific energy consumption, or minimum energy efficiency, of energy consuming machines and appliances manufactured or marketed in Brazil (BRASIL, 2001).

In the last decades, the residential sector presented a significant increase in the consumption of electric energy, especially in 2014, where energy consumption reached $24.9 \%$ of the total energy consumed in the country, according to the National Energy Balance (BRAZIL, 2015). Faced with this fact, it is necessary to use energy rationally, to somehow prevent or delay investments in the expansion of the electric system.

Avoiding the expansion of the electric system means "making available" more resources to be invested in health and education, besides not generating environmental impacts with possible floods, and the displacement of people (MORISHITA, 2011). According to Geller (apud LAMBERTS; DUTRA; PEREIRA, 2014), "it is cheaper to save energy than to provide it". The vast majority of the projects currently being built do not take into account Energy Efficiency in Building (EEE), not even thermal comfort, but only the low execution 
cost. There is a distorted view on the market that EEE projects, materials and equipment do not provide financial returns.

Thus, this study aims to propose alternatives to increase the EEE level of a residential set of the My House My Life Program for level A. In addition, the costs for execution and the calculation of the investment payback are analyzed.

With the benefits of labeling, the possibility of a new market arises, where consumers tend to favor projects that, in addition to providing low energy consumption, are more environmentally friendly.

\section{National Energy Conservation Label - ENCE}

In the face of the oil crises of the 70s and 80s, INMETRO started in 1984 a discussion with society about energy conservation, with the aim of informing consumers about the energy efficiency of each product and contribute to the reduction of its consumption, stimulating them to make a smarter purchase. This project grew and became the PBE (BRAZIL, 2006).

It was then in the year 2001 after the approval of the Energy Efficiency Act - EE that it was established maximum levels of specific energy consumption, or minimum levels of energy efficiency. It began to be mandatory the labeling for some sectors of industry, such as home appliances.

After the issuance of household appliances labels, PBE Edifica was developed, with building labels. Commercial, service and public buildings follow the Technical Regulation of Quality for the Energy Efficiency Level of Commercial, Services and Public Buildings (RTQ-C), being classified in general or partial form and the residential buildings follow the RTQ-R, which subdivides it into three types: Autonomous Housing Unit (UH), Multifamily Building and Areas of Common Use.

For the labeling of the $\mathrm{UH}$ are considered the requirements regarding the thermal performance of the envelope, the efficiency of the water heating systems and any bonuses. In this case, it is not possible to obtain partial classification of their systems, i.e. it is not executable to classify only the envelope or the water heating system (BRASIL, 2012). The 
bonuses are attributed to the initiatives that increase the efficiency of the $\mathrm{UH}$, through an evaluation of the following items: ventilation and natural lighting, rational use of water, air conditioning, artificial lighting, ceiling fans, refrigerators, and individualized measurement.

The systems are evaluated separately, obtaining a number of points corresponding to each requirement (Equivalent Numerical - EqNum), where they are placed in an equation (Equation 1), which takes into account the geographic region (Table 1) in which the building belongs. The result obtained refers to the final UH score, adding the possible bonuses which will result in the total score (PTUH) and in its efficiency level, which it varies from A (more efficient) to $E$ (less efficient), according to Figure 1 (BRASIL, 2012).

$$
P T_{U H}=(a \times E q N u m E n v)+[(1-a) \times E q N u m A A]+\text { Bonuses }
$$

Table 1 - Coefficient of Equation 1

\begin{tabular}{l|l|l|l|l|l}
\hline \multirow{2}{*}{ Coefficient } & \multicolumn{4}{l}{ Geographic region } \\
\cline { 2 - 6 } & North & Northeast & Midwest & Southeast & South \\
\hline $\mathrm{a}$ & 0.95 & 0.90 & 0.65 & 0.65 & 0.65 \\
\hline
\end{tabular}

Source: Adapted from BRAZIL, 2012.

Figure 1 - Efficiency Levels

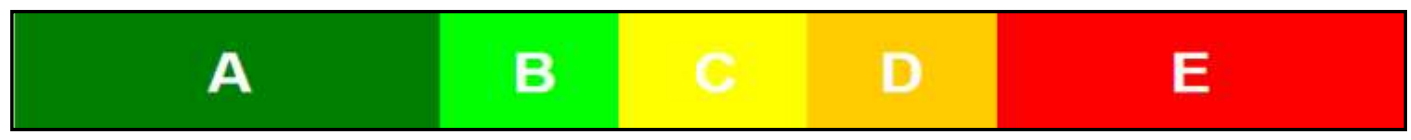

Source: BRAZIL, 2012.

The ENCE, which is an instrument of voluntary adhesion for the moment, has the objective of classifying the buildings. There are already hundreds of labels issued in Brazil. It can be issued in the design stage or in a building already built, through the prescriptive method or by computer simulation. It is advisable to issue ENCE from the project stage, as it is possible to obtain better results with lower investments, it can reach $50 \%$ savings (PROCEL, 2015). 


\section{Methodology}

In this topic the procedures adopted to determine the current level of energy efficiency of a residential set of the My Home My Life (MCMV) program through RTQ-R are described. They are the costs involved to reach level $A$, the determination of the energy consumption in both levels by thermo-energetic simulation and by the calculation of the payback. The data referring to the project were obtained through architectural design, engineering, measurements and visits in loco.

\subsection{Study object}

The residential set of the federal housing program My House My Life is located in the Florais da Amazônia neighborhood in the municipality of Sinop - MT. The city has 129,916 inhabitants (IBGE, 2015), it is located about $500 \mathrm{~km}$ from the capital Cuiabá and according to Laco (2013) Sinop is classified according to climatic data of the city of Vera - MT, Bioclimatic Zone 5.

For the accomplishment of the present research, a residence was evaluated by the prescriptive method of RTQ-R and by thermo-energetic simulation. There are a total of 25 houses built in the residential, they are identical and have an area of $62.63 \mathrm{~m}^{2}$; consisting of 02 rooms, living room, kitchen, service area, bathroom and balcony as shown in Figure 2 .

(Continue...) 
Figure 2 - Floor plan

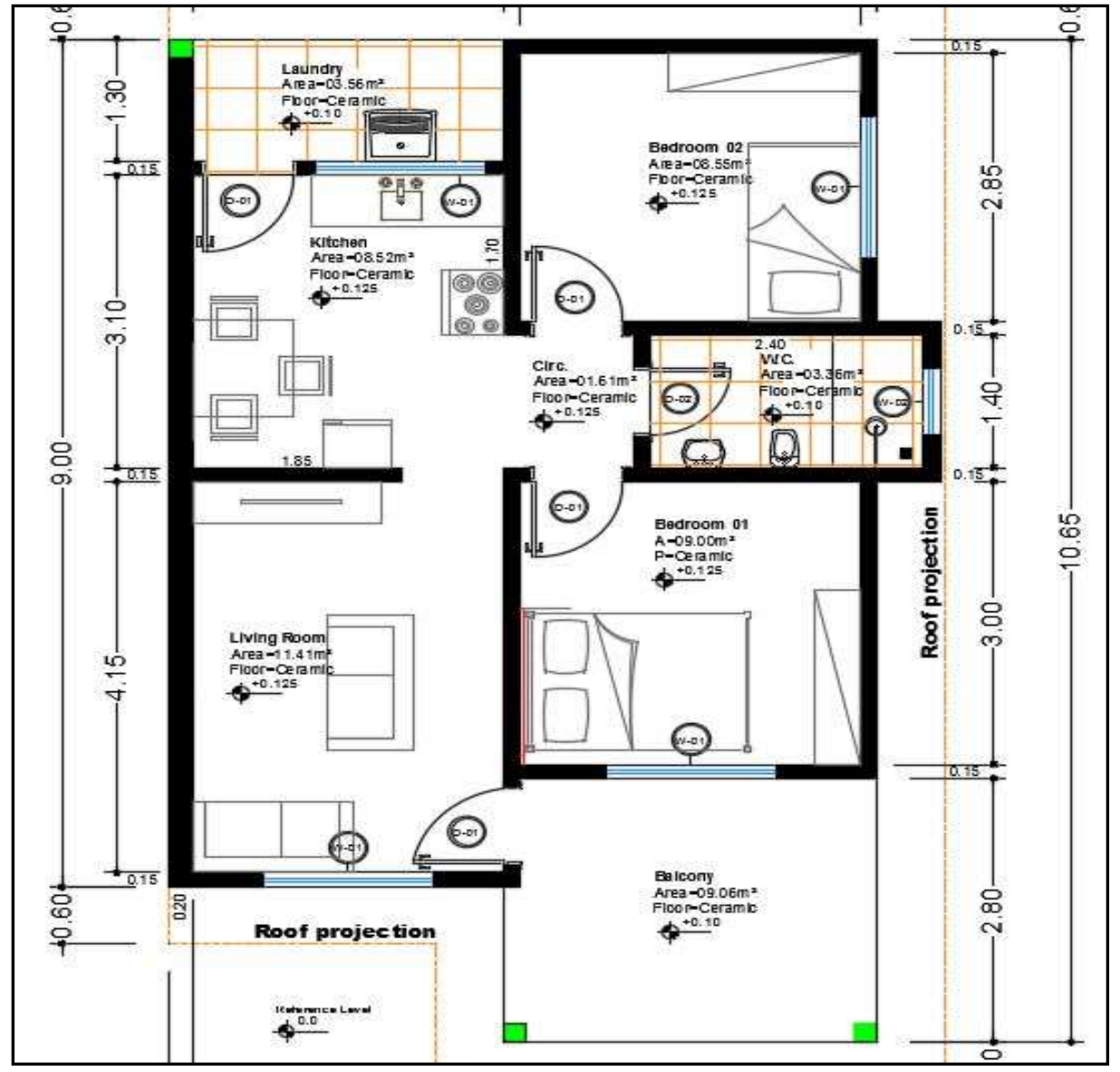

Source: Adapted from the construction company.

\subsection{Characterization of residential buildings}

The architectural characteristics of the buildings were evaluated according to the construction practices and materials used in the execution. This evaluation used the prescriptive method, where the necessary data were obtained through the descriptive memorial, architectural design, on-site verification of the building, bibliographic review and by NBR 15220 (ABNT, 2005) and 15575 (ABNT, 2013). The constructive guidelines adopted are shown in Table 2.

Table 2: Construction guidelines for ZB 5

\section{External fences}

Wall 


\begin{tabular}{l|l|l|l}
\hline Averages & Shade openings & $\begin{array}{l}\text { Light reflective } \\
\mathrm{U} \leq 3.60\left(\mathrm{~W} / \mathrm{m}^{2} . \mathrm{K}\right)\end{array}$ & $\begin{array}{l}\text { Light isolated } \\
\mathrm{U} \leq 2.00\left(\mathrm{~W} / \mathrm{m}^{2} . \mathrm{K}\right)\end{array}$ \\
\hline
\end{tabular}

Source: Adapted from ABNT, 2005.

\section{Determination of energy efficiency}

The energy efficiency of the residences was determined following the steps described by the prescriptive method of the RTQ-R (Brazil, 2012). It was being individually evaluated the envelope and the water heating system, in order to be able to classify the level of energy efficiency as shown in Table 3.

Table 3 - Numerical Equivalent (EqNum)

\begin{tabular}{l|l}
\hline Efficiency level & EqNum \\
\hline A & 5 \\
\hline B & 4 \\
\hline C & 3 \\
\hline D & 2 \\
\hline E & 1 \\
\hline
\end{tabular}

\subsection{Envelope}

The calculation of the efficiency of the envelope was determined through the spreadsheet provided by the Brazilian Labeling Program (PBE), where there were inserted: the bioclimatic zone, the constructive characteristics and the prerequisites.

With the completion of the spreadsheet the degree-hours indicator for cooling and the relative consumption for refrigeration were obtained, as well as the level of efficiency of the enclosure for the naturally ventilated housing unit and if artificially refrigerated for each of the extended stay environments, being the room and dormitories. 


\subsection{Water heating system}

The calculation of the efficiency of the water heating system was determined by a specific PBE worksheet. The hot water is supplied exclusively by electric shower. In this case, only filling the fields referring to the prerequisites of the system and the value of the power of the equipment, it was possible to obtain the efficiency level of the electric heating system.

\subsection{Reformulation of the MCMV project with ENCE level A}

In the reformulation part of the project, the classification of the Envelope and of the Water Heating System were analyzed, and from these results, it was made changes so that the buildings could reach level A of energy efficiency.

\subsection{Determination of costs to achieve ENCE level A}

With the project reformulations carried out, the replaced materials were collected and the costs were estimated so that these buildings could reach the level of efficiency still in the design phase.

This survey was carried out according to the catalog of analytical compositions together with the catalog of cost of compositions and prices of inputs, both provided by the National System of Costing and Indices of Construction - SINAPI (BRAZIL, 2015)

\subsection{Determination of the energy savings provided by ENCE level A}

With the actual situation of the project and with the changes made in the envelope and in the water heating system, the new electric energy consumption of the building was quantified by means of thermo-energy simulation using DesignBuilder software.

\subsection{Calculation of investment payback}

The calculation of the payback was made after the lifting of the costs to reach ENCE level A and the energy savings provided, with the value in Reais found in the economy, the calculation of the time needed for the property owner to recover his investment through Equation 2 was performed. 
payback $=\frac{\text { investment }}{\text { Annual cash flow }}$

However, it is necessary to determine if the investment is profitable or not, by calculating the Net Present Value (NPV), which is determined by Equations 3 and 4 developed by Hansen and Mowen (2001). In Equation 3 the internal rate of return was determined, which is the interest rate that establishes the NPV:

$I=\frac{\sum F C t}{(1+i)^{t}}$

Where:

$\mathrm{i}=$ internal rate of return;

$\mathrm{FCt}=$ the cash inflow to be received in period $t$, with $t=1 \ldots \mathrm{n}$;

$I=$ present value of project cost (initial disbursement).

For the calculation of the factor that measures the profitability of an investment, Equation 4 was used.

$V P L=\left[\frac{\sum F C t}{(1+i)^{t}}\right]-I_{\text {Equation } 4 .}$

Where:

$\mathrm{I}=$ present value of the project cost;

$\mathrm{FCt}=$ cash inflow to be received in period $t$, with $\mathrm{t}=1 \ldots \mathrm{n}$;

$\mathrm{i}=$ required rate of return;

$\mathrm{n}=$ project lifetime;

$\mathrm{t}=$ period of time.

After calculating the value of NPV performed, the following verification was performed: if the value found is greater than zero, the investment is profitable, if it is less than zero, the 
investment is not profitable and if it is equal to zero one must make a decision whether or not to accept the investment. Another factor that should be considered is the opportunity cost, which it is analyzed according to the Selic interest rate, made available by the Central Bank.

\section{Analysis of Results}

\subsection{Walls}

The external and internal walls of the residences are composed of 6 -hole bricks $(9.0 \times 14.0 \times 19.0 \mathrm{~cm})$, seated in the smallest dimension, with mortar for laying and framing with thicknesses equal to 1,0 and $2,5 \mathrm{~cm}$ respectively. The walls are $14.0 \mathrm{~cm}$ in total thickness.

The outer wall lining consists of two colors, one dark and one clear. The dark paint with absortance equals to 0.70 is used in the facade of the room and in the details of the pillars, the light paint with absortance equals to 0,40 is used in the other facades.

In the case of external walls NBR 15220-3 (ABNT, 2005) defines constructive guidelines, which are not followed in this residential set. The standard defines that the wall should be "light reflective". What differs from the external walls used, as the walls are not reflective because they are coated with medium to high absorptive colors. Table 4 shows the absorptance and emissivity values adopted in this work for light green and dark green.

Table 4 - Absorptance $(\alpha)$ and emissivity $(\varepsilon)$

\begin{tabular}{l|l|l}
\hline Painting & $\boldsymbol{\alpha}$ & E \\
\hline White & 0.2 & 0.9 \\
\hline Yellow & 0.3 & 0.9 \\
\hline Light Green & 0.4 & 0.9 \\
\hline " Aluminum " & 0.4 & 0.5 \\
\hline Dark Green & 0.7 & 0.9 \\
\hline Red & 0.74 & 0.9 \\
\hline
\end{tabular}




\begin{tabular}{l|l|l}
\hline Black & 0.97 & 0.9 \\
\hline
\end{tabular}

Source: Adapted from ABNT, 2005

\subsection{Roof}

The cover of the residences is composed of natural concrete tiles with thickness of 2.5 $\mathrm{cm}$, absorptance equals to 0.65 and polyvinyl chloride (PVC) lining with thickness of $8.0 \mathrm{~mm}$.

Because the NBR 15220 does not bring the thermal properties of the roof with concrete tile, air chamber and PVC liner, it was necessary to determine the physical properties of the concrete tile to later calculate the thermal transmittance and thermal capacity based on the standard.

In the laboratory test the tile was immersed in water for three days and then it was weighted in order to find the weight of the tile saturated. The volume was obtained by immersing the tile in a bucket completely filled with water, thus the extravasated volume was the volume of the tile.

Table 5 - Concrete tile properties

\begin{tabular}{l|l|l}
\hline Tile weight $\mathbf{( K g )}$ & Volume $\left.\mathbf{( m}^{\mathbf{3}}\right)$ & Density $\mathbf{( K g / \mathbf { m } ^ { \mathbf { 3 } } )}$ \\
\hline 4.85 & 0.00215 & 2255.81 \\
\hline
\end{tabular}

Source: Authorship, 2015

The value of the thermal transmittance was determined by Equation 5 .

$$
U=\frac{1}{R_{T}}(5)
$$

Where RT represents the total thermal resistance of the cover, obtained by summing the resistances of the cover components, as shown in Equation 6.

$$
R_{T}=\sum_{\lambda(6)}^{e}
$$


In this equation e represents the thickness $(\mathrm{mm})$ and $\Lambda$ the thermal conductivity (W / $\left.\mathrm{m}^{2} . \mathrm{K}\right)$ of the component, values obtained in Table 6.

Table 6 - Density $(\rho)$, thermal conductivity $(\Lambda)$ and specific heat $(c)$

\begin{tabular}{l|l|l|l}
\hline Material & $\rho\left(\mathbf{k g} / \mathbf{m}^{\mathbf{3}}\right)$ & $\boldsymbol{\Lambda}[\mathbf{w} /(\mathbf{m} \cdot \mathbf{k})]$ & $\mathbf{c}[\mathbf{k J} / \mathbf{( k g . k ) ]}$ \\
\hline Concrete tiles & 2255.81 & 1.15 & 1 \\
\hline PVC & 1300 & 0.2 & 0.96 \\
\hline Glass wool & 45 & 0.045 & 0.7 \\
\hline
\end{tabular}

Source: Adapted from ABNT, 2005.

In the calculation of the total thermal resistance, the thermal resistance of the air, the internal surface resistance (Rsi) and the external surface resistance (Rse), obtained in Tables 7 and 8 , were considered.

Table 7 - Thermal resistance of air

\begin{tabular}{l|l|lc}
\hline $\begin{array}{l}\text { Nature of the surface of the inner } \\
\text { tube }\end{array}$ & $\begin{array}{l}\text { Thickness of the inner } \\
\text { tube }(\mathbf{c m})\end{array}$ & $\begin{array}{l}\text { Descending heat } \\
\text { flow }\end{array}$ \\
\hline Surface of high emissivity $\varepsilon>0.8$ & e $>5$ & 0.21 \\
\hline
\end{tabular}

Source: Adapted from ABNT, 2005.

Table 8 - Internal and external surface thermal resistance

\section{Direction of the descending heat flow}

\begin{tabular}{l|l}
\hline Rsi $\left(m^{2} . K\right) / W$ & 0.17 \\
\hline Rse $\left(m^{2} . K\right) / W$ & 0.04 \\
\hline
\end{tabular}

Source: Adapted from ABNT, 2005.

The thermal capacity was obtained by the product of the thickness with the specific heat and with the density of the constituent elements of the cover, as shown in Equation 7. 


$$
C_{T}=\sum \operatorname{exc} \times \rho_{(7)}
$$

According to the constructive guidelines of the standard, the coverage must be "light insulated". However, these characteristics were not fulfilled in the residential complex. Thus, the results obtained are shown in Table 9.

Table 9 - Thermal transmittance and thermal capacity

\begin{tabular}{l|l|l}
\hline $\begin{array}{l}\text { Residence } \\
\text { Level D }\end{array}$ & $(\mathrm{U}) \mathrm{W} / \mathrm{m}^{2} . \mathrm{K}$ & $\mathrm{CT}\left(\mathrm{KJ} / \mathrm{m}^{2} . \mathrm{K}\right)$ \\
\cline { 2 - 3 } & 2,08 & 66,38 \\
\hline
\end{tabular}

Source: Authorship, 2015.

\subsection{Wall openings}

According to NBR 15.575 (ABNT, 2013), the openings need shading system and must have minimum dimensions for ventilation, equal or greater than $8 \%$ of the floor area of each extended dwelling environment including the kitchen. There was no compliance with the ventilation in the room alone.

\subsection{Power Rating}

\subsubsection{Envelope}

The envelope was evaluated with the aid of the spreadsheet provided by (PBE) using the following data: bioclimatic zone; floor and cover situation; thermal transmittance, thermal capacity and absorption of the cover and external walls; constructive feature; areas of external walls of the environment; areas of openings; characteristics of the openings; general features; and prerequisites. Thus, the results obtained are presented in Tables 10, 11,12 and 13.

Table 10: Degree-hour and relative consumption indicator for refrigeration

\begin{tabular}{l|l|l|l}
\hline Environment & Room & Bedroom 2 & Bedroom 1 \\
\hline
\end{tabular}




\begin{tabular}{l|l|l|l|l}
\hline \multirow{2}{*}{$\begin{array}{l}\text { Degrees-hour } \\
\text { Indicator for Cooling }\end{array}$} & \multirow{2}{*}{$\mathrm{C} . \mathrm{h}$} & $\mathrm{D}$ & $\mathrm{D}$ & $\mathrm{D}$ \\
\cline { 3 - 5 } & & 14646 & 12669 & 12498 \\
\hline $\begin{array}{l}\text { Relative Consumption } \\
\text { for Cooling }\end{array}$ & $\mathrm{kWh} / \mathrm{m}^{2}$.year & $\mathrm{D}$ & $\mathrm{D}$ & $\mathrm{D}$ \\
\cline { 3 - 5 } & & 0 & 60.160 & 57.303 \\
\hline
\end{tabular}

Source: Adapted from PBE, 2014.

Table 11 - Final score of the envelope

\begin{tabular}{l|l}
\hline \multirow{2}{*}{ Envelope for Summer } & $\mathrm{D}$ \\
\cline { 2 - 2 } & 2.00 \\
\hline
\end{tabular}

Source: Adapted from PBE, 2014.

Table 12 - Envelopment pre-requirements per environment

\begin{tabular}{|c|c|c|c|c|}
\hline & & Liv. Room & Bedroom 2 & Bedroom 1 \\
\hline External Walls & Uwall, Ctwall e awall meet? & Yes & Yes & Yes \\
\hline Roof & Uroof, Ctroof e aroof meet? & No & No & No \\
\hline $\begin{array}{l}\text { Lighting and natural } \\
\text { ventilation }\end{array}$ & Is the environment a dormitory? & No & Yes & Yes \\
\hline \multirow{3}{*}{ Natural Lighting } & Opening area for lighting $\left[\mathrm{m}^{2}\right]$ & 1.52 & 1.52 & 1.52 \\
\hline & Ai/Auamb (\%) & 13.31 & 17.76 & 16.87 \\
\hline & Meets $12.5 \% ?$ & Yes & Yes & Yes \\
\hline \multirow{6}{*}{ Natural Ventilation } & $\begin{array}{l}\text { Opening area for } \\
\text { ventilation }\left[\mathrm{m}^{2}\right]\end{array}$ & 0.74 & 0.74 & 0.74 \\
\hline & Av/Auamb (\%) & 6.51 & 8.68 & 8.25 \\
\hline & Meets Minimal \%? & No & Yes & Yes \\
\hline & Opening type & Sliding & Sliding & Sliding \\
\hline & Opening possible closing? & Yes & Yes & Yes \\
\hline & Meets? & Yes & Yes & Yes \\
\hline
\end{tabular}

Source: Adapted from PBE, 2014.

Table 13 - Envelope Prerequisites 


\begin{tabular}{|c|c|c|}
\hline \multicolumn{2}{|l|}{ Individual energy measurement? } & Yes \\
\hline \multirow{6}{*}{ Cross ventilation } & Openings Area North orientation & 0.92 \\
\hline & Openings Area South orientation & 0 \\
\hline & Openings Area East orientation & 1.48 \\
\hline & Openings Area West orientation & 0.74 \\
\hline & $\mathrm{A} 2 / \mathrm{A} 1$ & 1.12 \\
\hline & Meets A2 / A1 greater than or equal to 0.25 ? & Yes \\
\hline \multirow{3}{*}{$\begin{array}{l}\text { Bathrooms with natural } \\
\text { ventilation }\end{array}$} & $\mathrm{N}^{\circ} \mathrm{BWC}$ & 1 \\
\hline & $\mathrm{N}^{\circ}$ Bathrooms with natural ventilation & 1 \\
\hline & Meets $50 \%$ or more of the bathrooms? & Yes \\
\hline
\end{tabular}

Source: Adapted from PBE, 2014.

It is important to note that the opening area values for illumination and ventilation were determined in loco by measurements and are shown in Table 14.

Table 14 - Percentage of opening for lighting and natural ventilation

\begin{tabular}{l|l|l}
\hline & Lighting & Ventilation \\
\hline Window 1 & $92 \%$ & $45 \%$ \\
\hline Window 2 & $86 \%$ & $43 \%$ \\
\hline
\end{tabular}

Source: Authorship, 2015.

\subsubsection{Water heating system}

The water heating system was evaluated using the spreadsheet provided by (PBE), using data regarding of the prerequisites, the power of the shower and the demand of use of this system. The results are shown in Table 15.

Table 15 - Final score of the water heating system

\begin{tabular}{l|l|l}
\hline $\begin{array}{l}\text { Electric walk-through } \\
\text { heaters, electric showers and } \\
\text { electric faucets }\end{array}$ & Power of the shower (W) & 5500 \\
\cline { 2 - 3 } & Demand & $100 \%$ \\
\hline
\end{tabular}




\begin{tabular}{l|l|l}
\hline \multirow{2}{*}{ Classification } & E \\
\cline { 3 - 3 } & & 1 \\
\hline
\end{tabular}

Source: Adapted from PBE, 2014.

\subsubsection{Bonifications}

The residential set as a whole and the specific residence evaluated, presented the following bonuses: depth 0.2 and reflectance ceiling 0.1 .

\subsubsection{Final score}

The value of the final score of the UH was calculated using data on the envelope, heating system, prerequisites and bonuses. The result of this evaluation is shown in Table 16.

Table 16 - Level D final score

\begin{tabular}{|c|c|c|}
\hline \multirow{14}{*}{ Final Score } & Identification & \\
\hline & \multirow{2}{*}{ Envelope for Summer } & $D$ \\
\hline & & 2.00 \\
\hline & \multirow{2}{*}{ Envelope for Winter } & Not applicable \\
\hline & & 0.00 \\
\hline & \multirow{2}{*}{ Water Heating } & $E$ \\
\hline & & 1.00 \\
\hline & \multirow{2}{*}{$\begin{array}{l}\text { Numerical Equivalent of } \\
\text { Envelope }\end{array}$} & $D$ \\
\hline & & 2.00 \\
\hline & \multirow{2}{*}{$\begin{array}{l}\text { Wrapping if artificially } \\
\text { refrigerated }\end{array}$} & $D$ \\
\hline & & 2.00 \\
\hline & Bonifications & 0.30 \\
\hline & Region & Midwest \\
\hline & Coefficient a & 0.65 \\
\hline \multicolumn{2}{|c|}{ UH final classification } & $\mathrm{D}$ \\
\hline
\end{tabular}


Total score

\subsection{Reformulation of the MCMV project with ENCE level A}

The reformulation was based on the constructive characteristics presented by NBR 15575 (ABNT, 2013) and the lower investment cost required to reach level A.

\subsubsection{Walls}

In the part of the walls it was necessary to change the color of the coating, from colors with medium to high absorptance to a color of low absorptance, that is, the white color.

\subsubsection{Roof}

Because the thermal transmittance value of the cover is not in the range required by the standard, a thermal blanket of $2.5 \mathrm{~cm}$ glass wool was provided and the replacement of the concrete tiles in gray to white ones. With the application of the thermal blanket the transmittance decreased to $0.96 \mathrm{~W} / \mathrm{m}^{2} . \mathrm{K}$, the thermal capacity to $67.17 \mathrm{KJ} / \mathrm{m}^{2} . \mathrm{K}$ and with the change of tiles the absorbance reduced from 0.65 to 0.20 .

\subsubsection{Wall openings}

In order to meet all prerequisites for opening the walls, it was necessary to increase the room window from $1.5 \mathrm{~m} \times 1.1 \mathrm{~m}$ to $2.0 \mathrm{~m} \times 1.1 \mathrm{~m}$ to obtain the effective ventilation opening area.

\subsubsection{Water heating system}

The electric water heating system was changed to solar heating, being scaled according to the spreadsheet provided by (PBE) and guaranteeing a minimum solar fraction of $70 \%$, with backup by electrical resistance.

Using the minimum criteria required by the RTQ-R, the results presented in Table 17 were obtained for a collector labeled A, with an optical efficiency factor $\operatorname{Fr}(T \alpha) n=0.729$, $\mathrm{FrUL}=4,511$ global loss coefficient and reservoir with the lowest specific monthly energy loss of $0.13 \mathrm{KWh} /$ month / I. 
Table 17 - Solar heating sizing

\begin{tabular}{l|l}
\hline Stored water volume & $200 \mathrm{~L}$ \\
\hline Number of collectors & 2 \\
\hline Collector Area & $2.14 \mathrm{~m}^{2}$ \\
\hline Total Collector Areas & $4.28 \mathrm{~m}^{2}$ \\
\hline Varmaz/Collector Areas & 46.73 \\
\hline Annual solar fraction & $71.67 \%$ \\
\hline
\end{tabular}

Source: Adapted from PBE, 2014

\subsubsection{Bonifications}

The bonuses given in Table 18 were considered to achieve ENCE level A.

Table 18 - Bonifications

\begin{tabular}{l|l}
\hline Depth & 0.2 \\
\hline Reflectance ceiling & 0.1 \\
\hline Artificial lighting & 0.1 \\
\hline Ceiling Fans & 0.1 \\
\hline Refrigerators \& Freezers & 0.1
\end{tabular}

Source: Authorship, 2015

\subsubsection{Final Score}

The value of the final score of the UH is calculated automatically after all data related to the envelope, heating system, prerequisites and bonuses are entered. The result of this evaluation is shown in Table 19.

Table 19 - Final score level A

\begin{tabular}{l|l|l}
\hline \multirow{2}{*}{ Total score } & Identification & \\
\cline { 2 - 3 } & Envelope for Summer & C \\
\hline
\end{tabular}




\begin{tabular}{l|l|l}
\hline \multirow{2}{*}{ Envelope for Winter } & 3.31 \\
\cline { 2 - 3 } & \multirow{2}{*}{ Water Heating } & Not applicable \\
\cline { 2 - 3 } & & 0.00 \\
\cline { 2 - 3 } & Numerical Equivalent of Envelope & A \\
\cline { 2 - 3 } & & 3.31 \\
\cline { 2 - 3 } & Wrapping if artificially refrigerated & C \\
\cline { 2 - 3 } & & 2.52 \\
\cline { 2 - 3 } & Bonifications & 0.60 \\
\cline { 2 - 3 } & Region & Midwest \\
\cline { 2 - 3 } & Coefficient a & 0.65 \\
\hline Total score & & A \\
\hline
\end{tabular}

Source: Adapted from PBE, 2014.

5.5.8 Determination of costs to achieve ENCE level A

The costs per residence to raise the efficiency level from $D$ to $A$ still in the design phase are shown in Table 20.

Table 20 - Costs to raise efficiency from level $D$ to $A$ per residence

\begin{tabular}{l|l}
\hline $\begin{array}{l}\text { Water heating system (Installation } \\
\text { Collectors + Reservoir) }\end{array}$ & $\mathrm{R} \$ 3,089.68$ \\
\hline White concrete tile & $\mathrm{R} \$ 700.00$ \\
\hline Living Room Window & $\mathrm{R} \$ 144.32$ \\
\hline Thermal blanket of glass wool $-\mathbf{e}=\mathbf{2 , 5} \mathbf{c m}$ & $\mathrm{R} \$ 4,195.87$ \\
\hline Painting & $-\mathrm{R} \$ 39.10$ \\
\hline Total & $\mathrm{R} \$ 8,090.77$ \\
\hline
\end{tabular}

Source: Authorship, 2015. 
It is important to emphasize that the costs related to the room window and the tiles were based on the price difference between one material and another, in the case of the window the difference of $0.5 \mathrm{~m}$ in width was an increase of 144.32 Reais, and in the case of tiles the difference in color was 0.70 Reais per tile. In the case of painting a reduction in value was obtained, due to the replacement of the original dark paint with white paint.

5.5.9 Determination of the energy savings provided by ENCE level A

Through the DesignBuilder software, the simulation was performed for each of the projects, where it followed the RTQ-R procedures for simulation of artificially conditioned residential buildings. Table 21 shows the inputs used in the simulation.

Table 21 - Simulation Inputs

\begin{tabular}{l|l|l|l}
\hline \multirow{2}{*}{ Roof } & & Level D & Level A \\
\hline \multirow{2}{*}{ Wall } & Transmittance & $2.08\left(\mathrm{~W} / \mathrm{m}^{2} . \mathrm{K}\right)$ & $0.96\left(\mathrm{~W} / \mathrm{m}^{2} . \mathrm{K}\right)$ \\
\cline { 2 - 4 } & Absorptance & 0.65 & 0.2 \\
\hline \multirow{2}{*}{ Infiltration of air } & Transmittance & $2.48\left(\mathrm{~W} / \mathrm{m}^{2} . \mathrm{K}\right)$ & $2.48\left(\mathrm{~W} / \mathrm{m}^{2} . \mathrm{K}\right)$ \\
\cline { 2 - 4 } & Absorptance & $\begin{array}{l}0.70-\text { Dark color } 0.40 \\
- \text { Bright color }\end{array}$ & 0.2 \\
\hline HVAC & Constant rate & $1.00(\mathrm{ac} / \mathrm{h})$ & $1.00(\mathrm{ac} / \mathrm{h})$ \\
\hline Equipment & Cooling & $3.30(\mathrm{Cop})$ & $3.30(\mathrm{Cop})$ \\
\hline Openings & Living room & $1.5\left(\mathrm{~W} / \mathrm{m}^{2}\right)$ & $1.5\left(\mathrm{~W} / \mathrm{m}^{2}\right)$ \\
\hline \multirow{2}{*}{ Lighting } & Shower & $1266.70\left(\mathrm{~W} / \mathrm{m}^{2}\right)$ & $358.86\left(\mathrm{~W} / \mathrm{m}^{2}\right)$ \\
\hline
\end{tabular}

Source: Authorship, 2015.

(Continue...) 
Figure 3 shows the results regarding energy consumption according to the projected efficiency level.

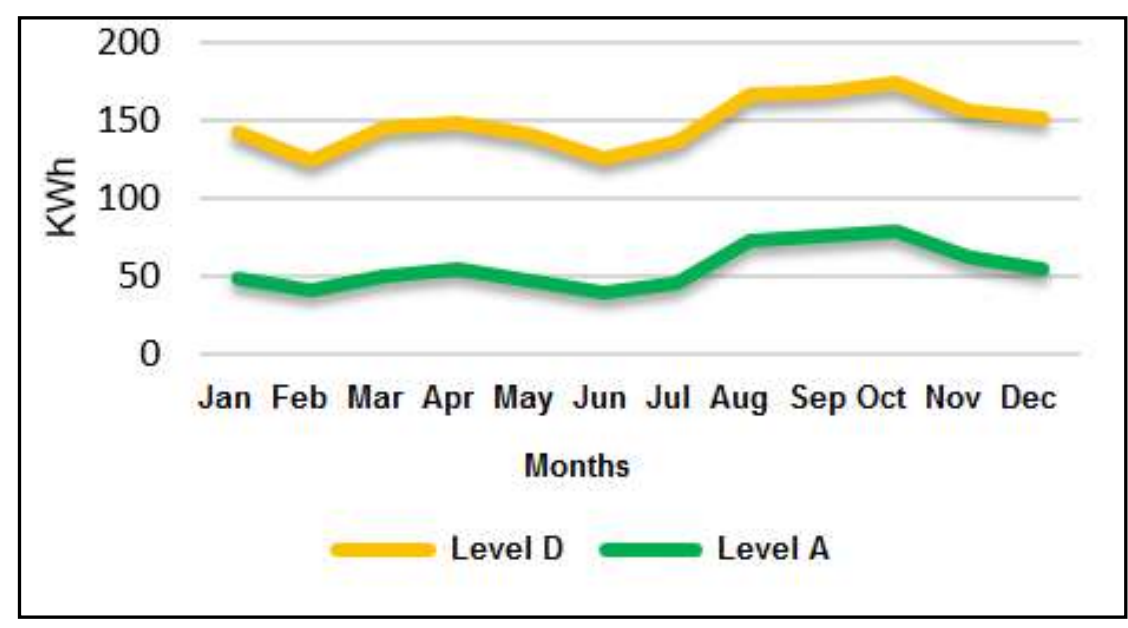

Source: Authorship, 2015.

The changes made in the project resulted in an average monthly reduction of 92.72 $\mathrm{KWh}$, and consequently an annual reduction of 1,122.65 KWh. The annual energy consumption corresponding to each project are shown in Table 22.

Table 22 - Annual energy consumption

\begin{tabular}{l|l}
\hline Level D & $1,777.85 \mathrm{KWh}$ \\
\hline Level A & $665.20 \mathrm{KWh}$ \\
\hline
\end{tabular}

Source: Authorship, 2015.

\subsubsection{Calculation of investment payback}

With the value of energy savings found through thermos energy simulation, the value in Reais was determined using a tariff of $R \$ 0.70$ per $\mathrm{kWh}$. The total value of $R \$ 778.85$ was calculated considering the use of solar heating in $100 \%$. However, considering the size achieved with an annual solar fraction of $71.67 \%$, and the use of the electric backup in other periods, the annual energy savings decreased to $585.05 \mathrm{kWh}$. Thus, the calculation of payback, IRR and NPV took into account the two cases, that is, the maximum and minimum economy possible according to the climatic conditions and the user's thermal preference (Table 23). 
Table 23 - Economic indicators

\begin{tabular}{l|l|l}
\hline & $\begin{array}{l}\text { Level A without considering } \\
\text { electrical backup }\end{array}$ & $\begin{array}{l}\text { Level A considering electric } \\
\text { backup }\end{array}$ \\
\hline Cash flow & $\mathrm{R} \$ 778.85$ & $\mathrm{R} \$ 585.05$ \\
\hline Return rate & $12 \%$ & $12 \%$ \\
\hline Investment & $\mathrm{R} \$ 8,090.77$ & $\mathrm{R} \$ 8,090.77$ \\
\hline Payback & 10.39 years & 13.83 years \\
\hline $\mathrm{NPV}$ & $-\mathrm{R} \$ 2,273.19$ & $-\mathrm{R} \$ 3,720.0$ \\
\hline IRR & $7.25 \%$ & $3.80 \%$ \\
\hline
\end{tabular}

Source: Authorship, 2015.

The economic indicators were calculated considering the useful life of the 20-year project, as stated in NBR 15.575 (ABNT, 2013) and the rate of return of 12\%, based on a Selic rate of $14.25 \%$, with only the income tax being deducted. Therefore, for a Selic rate of $14.25 \%$, none of the analyzed investments is feasible. The viability in this case would depend on a reduction in the value invested, in the increase of the kWh cost or in the reduction of the basic rate of interest.

\section{Conclusions}

The present research served to propose alternatives that increase the level of energy efficiency and confirm the hypothesis raised: the increase in construction costs to reach level A are lower than the savings provided over the lifetime of the building.

However, in Brazil's current economic situation, when we compare the investment to achieve ENCE level A with other forms of investment, the same is not feasible since, the feasibility would depend on possible government incentives in the purchase of equipment, the increase in the cost of kWh or in the current reduction of the SELIC rate. Currently, the Selic rate of $14.25 \%$ makes it impossible to invest at the cost of opportunity, becoming viable with $\mathrm{kWh}$ cost higher than $\mathrm{R} \$ 0.97$ or with basic interest below $9.5 \%$.

The results obtained classified the current dwellings at level $D$ and showed that few changes are necessary to reach level $A$, which they reduced energy consumption by $2 / 3$. 
Therefore, it is hoped that the results obtained will serve as guiding guidelines for ventures similar to MCMV.

\section{References}

ASSOCIAÇÃO BRASILEIRA DE NORMAS TÉCNICAS - ABNT. NBR 15220: Desempenho térmico de edificações. Rio de Janeiro: ABNT, 2005.

ASSOCIAÇÃO BRASILEIRA DE NORMAS TÉCNICAS - ABNT. NBR 15575: Edificações Habitacionais - Desempenho. Rio de Janeiro: ABNT, 2013.

BRASIL. Ministério de Minas e Energia - MME. Balanço Energético Nacional 2015 Relatório final. Ano base: 2014. Brasília, 2015.

BRASIL. Caixa Econômica Federal. Sistema Nacional de Pesquisa de Custos e Índices da Construção Civil - SINAPI. Custo de Composições. Disponível em: http://www.caixa.gov.br/Downloads/sinapi-a-partir-jul-2014-

mt/SINAPI_Custo_ref_Composicoes_MT_082015_Desonerado.pdf. Acesso em:10 Out. 2013.

BRASIL. Caixa Econômica Federal. Sistema Nacional de Pesquisa de Custos e Índices da Construção Civil - SINAPI. Custo de Composições Analítico. Disponível em: http://www.caixa.gov.br/Downloads/sinapi-catalogo-de-composicoes-

analiticas/SINAPI_CATALOGO_COMPOSICOES_ANALITICAS_FEVEREIRO_2015.pdf. Acesso em: 17 Abr. 2013

BRASIL. Caixa Econômica Federal. Sistema Nacional de Pesquisa de Custos e Índices da Construção Civil - SINAPI. Preços de Insumos. Disponível em: http://www.caixa.gov.br/Downloads/sinapi-a-partir-jul-2014-

mt/SINAPI_Preco_Ref_Insumos_MT_082015_NaoDesonerado.pdf. Acesso em:10 Out. 2015.

BRASIL. Lei $\mathbf{n}^{\circ} \mathbf{1 0 . 2 9 5 / 2 0 0 1}$, de 17 de outubro de 2001. Presidência da República. Casa Civil. Subchefia para Assuntos Jurídicos. Brasília, 2001. Disponível em: <http://www.planalto.gov.br/ccivil_03/leis/leis_2001/L10295.htm>. Acesso em: 22 mar. 2015.

BRASIL. Ministério do Desenvolvimento, Indústria e Comércio Exterior Instituto Nacional de Metrologia, Qualidade e Tecnologia - INMETRO. Regulamento Técnico da Qualidade para o Nível de Eficiência Energética de Edificações Residenciais - RTQ-R. Rio de Janeiro, 2012.

BRASIL. Ministério de Minas e Energia - MME. Consumo Final e Conservação de Energia Elétrica (1970 - 2005). Brasília, 2006. 
CARRIEL - Indústria Comércio e Construtora Carriel. Projeto Padrão. Sinop, 2015.

CRESESB - Centro de Referência para Energia Solar e Eólica Sérgio Brito. Irradiação Sola Diária Mensal. Disponível em: http://www.cresesb.cepel.br/index.php\#data. Acesso em: 12 jul. 2015.

HANSEN, D. R; MOWEN, M. M. Gestão de Custos - Contabilidade e Controle. $3^{a}$. ed. São Paulo: Pioneira Thonsom Learning, 2001.

LACO, M. Avaliação do desempenho térmico de habitações de interesse social: estudo de caso da NBR 15575 para o município de Sinop - MT. Artigo (Trabalho de Conclusão de Curso de Graduação em Bacharel em Engenharia Civil) - Universidade do Estado de Mato Grosso, Sinop.

LAMBERTS, R.; DUTRA, L.; PEREIRA, F. O. R. Eficiência Energética na Arquitetura. $3^{a}$. ed. Rio de Janeiro, 2014. v. 3.

MORISHITA, C. Impacto do Regulamento para Eficiência Energética em Edificações no Consumo de Energia Elétrica do Setor Residencial Brasileiro. Dissertação. Universidade Federal de Santa Catarina, Florianópolis, 2011.

PBE - Programa Brasileiro de Etiquetagem. Planilha de cálculo do desempenho da UH. Disponível em: http://www.pbeedifica.com.br/etiquetagem/residencial/planilhas-catalogos. Acesso em: 18 mai. 2015.

PBE - Programa Brasileiro de Etiquetagem. Planilha de cálculo de sistema de aquecimento de água: solar.

PNEF - Plano Nacional de Eficiência Energética. Premissas e Diretrizes Básicas na Elaboração do Plano. Brasília: MME. 2011.

PROCEL. Selo Procel Edificações. Site do Procel. Disponível em: http://www.procelinfo.com.br/main.asp?View=\%7b8E03DCDE-FAE6-470C-90CB922E4DD0542C\%7d. Acesso em: 17 abr. 2015.

TCPO - Tabelas de Composição de Preços para Orçamentos. 13ed. São Paulo: Pini, 2010. 